\title{
С.В. КУЗНЕЦОВА
}

\section{ДРЕВНЕРУССКАЯ МУЗЫКАЛЬНАЯ ОБРАЗНОСТЬ В КАНТАТЕ Г.В. СВИРИДОВА «СВЕТЛЫЙ ГОСТЬ»}

\begin{abstract}
Анализируется взаимосвязь музыкального и литературного текстов кантаты Г.В. Свиридова «Светлый гость» с точки зрения выявления в них древнерусской музыкальной образности. Рассматриваются мелодические, гармонические, стилистические, жанровые и композиционные особенности построения произведения, посредством которых осуществляется претворение в этом сочинении элементов древнерусской певческой традиции.
\end{abstract}

Ключевые слова: Свиридов Г.В., «Светлый гость», кантата, песнопения, цикличность, вариантность, колокольность.

K антата «Светлый гость» - необычное сочинение в творческом наследии Г.В. Свиридова. Замысел произведения восходит к 1962 году, а источником вдохновения композитора стала поэзия Сергея Есенина. Композитор выбрал стихотворения поэта, изданные в 1918 году. «Все они являются непосредственным откликом на события революции, которая понимается (трактуется, рассматривается) Есениным как начало обновления, духовного преобразования Родины, России. Отсюда идет образное мышление и словарь поэта», - писал композитор в своей книге [1, с. 202-203].

К середине 1960-х годов четко определилась композиция этого сочинения. Практически полностью был написан музыкальный материал. Однако в свет кантата вышла только в 1979 году. Клавир был издан издательством «Музыка» и представлял собой, как значилось на титульном листе, «переложение для пения с фортепиано автора» [2]. Такая помета не была случайной, она свидетельствовала о желании доработать сочинение. В 1980 году в одном из своих писем Свиридов сообщает: «Теперь моя задача: приготовить “Светлого гостя" и “Отчалившую Русь" (оркестровать окончательную редакцию и исполнить)» [1, с. 330]. К сожалению, ни то, ни другое произведение в окончательной редакции оркестровано не было, хотя работа над ними продолжалась все последующие десятилетия. Что-то непреходящее и наболевшее видел композитор в этой музыке, и потому бесконечно изменялись образы, тембры, инструментальный и исполнительский состав. Есть свидетельства, что те глубинные вопросы и проблемы, которые он хотел выразить, по мере того, как менялась жизнь, раскрывались все новыми гранями, и всё же оставались до конца нерешенными [1, с. 148-150, 157]. «Светлый гость» - неэтапное, «лейтмотивное» произведение Свиридова.

После ухода Мастера из жизни авторские редакции «Светлого гостя» были переданы его близкому другу, удивительно чуткому и проникновенному композитору Роману Семеновичу Леденеву. Именно он после тщательной и кропотливой работы довел оркестровку до конца. В оркестровой редакции Леденева первое исполнение кантаты состоялось в Санкт-Петербурге в Мариинском театре, в рамках «Невских хоровых ассамблей» 3 октября 2006 года. А мировая премьера сочинения прошла 8 июня 2006 года в Светлановском зале Московского международного Дома музыки. Оно прозвучало в заключительном концерте фестиваля «Всероссийские хоровые ассамблеи», посвященного 90-летию со дня рождения Г.В. Свиридова.

Формально жанр «Светлого гостя» определен как кантата. Как известно, это слово семантически восходит к итальянскому глаголу cantare, что в первом значении обозначает «петь», а образованное от него существительнoе «cantata», а также в первом значении - «пение» [3, с. 47]. Получается, что этим словом европейцы назвали свой «поющийся» жанр, истоки которого находятся в любовной вокальной лирике Средневековья и родственен мадригалу. Поэтому неудивительно, что сам Свиридов «Светлого гостя» кантатой не считал, называя песнопениями. Родившийся в Европе жанр оказался неподходящим для выражения той сферы мыслей и образов, какими наполнено это произведение. А вот жанр песнопений древний, исконно русский, глубинно народный, православный, - отзывает к тому внеличному и богоустремленному, выраженному в строках Баратынского: «Болящий дух врачует песнопенье» [4, с. 154].

Действительно, в образах «Светлого гостя» очень много своего, русского, первозданного. Выраженные Есениным в стихотворениях революционных лет мысли, настроения, страдания и надежды народа воплотились Свиридовым в музыкальную фреску революционной России. События начала XX века, непосредственно затронувшие семью композитора, будут сопровождать его на протяжении всей жизни, побуждая вновь и вновь возвращаться к ним в своих произведениях.

В «Светлом госте» шесть частей, и каждая проникнута библейскими образами и символами, как и в «Поэме памяти Сергея Есенина», и в «0тчалившей Руси». Вновь возникает сравнение Руси-России с распятым Христом, соответственно Богородица выступает матерью, заступницей Земли Русской, защищающей своего Сына - русский 
народ. Христианские мотивы прослеживаются и в композиционно-структурных особенностях построения песнопений. Шестичастный цикл, исполняемый без перерывов, attacca, представляет собой интереснейшую многоплановую картину. Ведущими принципами формообразования становятся цикличность, арочность и вариантность. Они присутствуют как на уровне сочинения в целом, так и на уровне частей, тем и микротем. В сочинении это проявляется в характерной для Свиридова концентрической форме (A-B-C-B-A) в сочетании с вариантами - элементами песенного повтора (В-С-В1-С1-В2-С2).

Принцип арочности ярко проявляется в образной сфере, которую условно можно разделить на три группы. Первая группа связана со светлой лирикой, молитвеннопроникновенной мелодикой, выражающей образ Богоматери в первой части и финале цикла. Вторая - с трагическими монологами, это вторая, четвертая части, также «монолог» хора на стыке пятой и шестой частей и хоровой унисон в начале шестой. Третья группа объединяет все хоровые части цикла и выражает соборность, народность, издревле скрепляющие русский народ.

Русский песенно-тематический процесс формообразования, основанный на вариантном принципе развития, наглядно проявляется в образовании тем: каждая часть основана на одной теме, прирастающей многократными куплетами-вариантами. Гибкое, часто незаметное мотивное, метро-ритмическое, фактурное обновление материала образует бесконечные тематические круги и формирует куплетные формы всего цикла. Думается, что такой принцип куплетности, претворенный во многих сочинениях, воспринимался Свиридовым в более общем философско-религиозном аспекте - как символ обновления всего живого, как цикличность жизни, как евангельский цикл, определяющий ход развития судьбы Родины.

Цикличность сочинения не хаотична, она троична: три драматургически значимые арки, три образные сферы. Семантика числа «три» имеет древние и глубокие корни, наиболее сильно, однако, проявившиеся в христианской традиции. Как отражение, принцип троичности наблюдается и в народном творчестве. В таких семантических значениях это воспринимается композитором, явив сплав евангельского и народного, проникновенно-лирического и трагического, монологичного и общехорового соборного, сплав трех сущностей русского духа, трех состояний не только божественной, но и человеческой судьбы.

Первая часть «0, Матерь Божья, спади звездой...» написана на одноименное стихотворение Есенина 1917-го года из цикла, связанного с образом Богородицы, ее заступничеством за Русскую Землю и русский народ. Вспоминая рассказанные поэтом истории, В.Л. ЛьвовРогачевский писал: «Есенин мне рассказывал, что, когда он в детстве читал “Богородицу", он всегда слова: "яко Спаса родила" заменял другими: “около Спаса родила". Он учился в большом торговом селе Спас, где был древний храм Спаса, и ему казалось, что там, около родного Спаса, и родился маленький Иисус <...> И недаром в полях, лесах, всюду ищет своего крестного товарища, все ему кажется, что где-либо “под пеньком голодный Спас"» [5, с. 175].

С детства Есенину были очень близки образы Христа и Богоматери. И это ощущение родного проникает в свиридовский номер: он наполнен светлой печалью, молитвенной лирикой и сосредоточенностью. Потому и мелодические линии исключительно плавны, совсем в традициях народной песенности и древнерусских знаменных распевов. Весь номер наполнен колокольностью: неспешные удары слышны как в сопровождении, так и в партиях солистов. В авторском переложении для фортепиано номер открывают четыре долгих удара-аккорда ми-бемоль мажора. Тональность светла и прозрачна, и соло сопрано написано в очень высокой тесситуре, это словно небесный голос, выписывающий образ Богоматери.

Пример 1

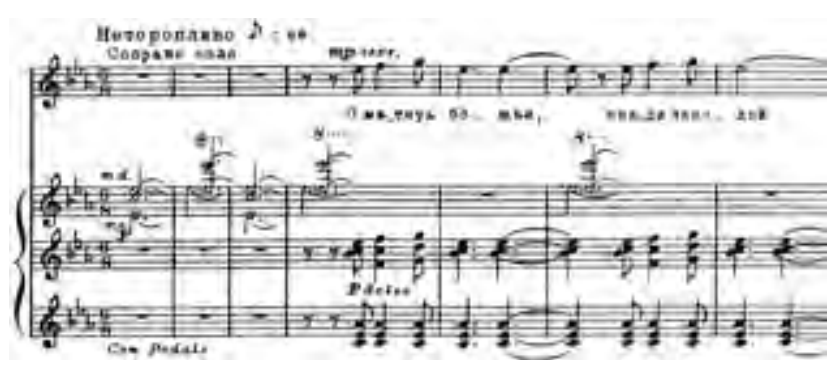

Начальной вокальной интонацией, что весьма знаменательно, является восходящий ход двумя большими секундами - а это ключевая интонация всего свода знаменных песнопений, называемого «согласием» обиходного звукоряда. При этом выполненное по I-II-III ступеням ми-бемоль мажора, оно становится логическим продолжением самого высокого, «тресветлого» согласия обиходного звукоряда. Как бы экспонированная в первых тактах, эта интонация затем на протяжении всего цикла прямо или косвенно будет участвовать в тематических новообразованиях. Такое возвышенное и умиротворенное начало очень символично: оно являет то исконное, истинно «древнерусско-музыкальное», внутренне противопоставленное энергичным началам европейских сонат и симфоний. Вступающее в двадцатом такте меццо-сопрано проводит сопрановую тему на октаву ниже, словно олицетворяя земные отзвуки небесных голосов и являя земное воплощение своего Сына в русских крестьянах.

Пример 2

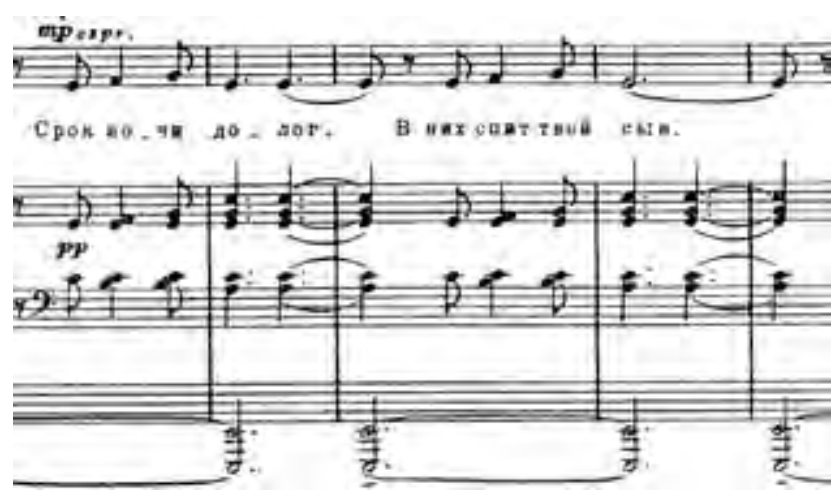


В этом номере наглядно реализуется принцип троичности. Он проявляется:

- в трехдольном ритме: размер 6/8 постоянен, не меняется на протяжении номера. Основная ритмическая фигура - четверть-восьмая. Вообще метроритмическая организация с удвоением-утроением каждого слога в конце смысловых построений была характерна для былинной традиции в целом. А в сочетании с мелодикой в ограниченном диапазоне и отсутствием внутренних конфликтов и контрастов прямо отзывает к песнопениям северорусских баллад и причитаний;

- в ладовых устоях мелодики. Натуральноладовые, а также квартово-квинтовые интонации образуют тяготения к трем тональным центрам:

- ми-бемоль мажору - до мажору - фа мажору.

- в композиционной структуре. Сочетание трех типов исполнения: соло сопрано - соло меццо-сопрано дуэт сопрано и меццо-сопрано.

Таким образом, вокальность, широкая, неторопливая, будто парящая мелодика рождают ощущение бесконечности, бескрайности родных просторов, по-матерински нежно согретых исцеляющим светом Богородицы.

Вторая часть - «Господи, я верую!». В ее основу положена первая главка поэмы «Пришествие», написанной поэтом в октябре 1917 года непосредственно по следам революционных событий. Критики отмечают в ней неоднозначное отношение поэта к свершившимся событиям. Андрею Белому, которому Есенин адресовал произведение, поэма очень понравилась, но - «снова революция как Крестный путь, как Голгофа» [6, с. 130]. «Снова», вероятно, потому что, как пишет М.Л. Слоним, «после прекрасной поэмы А. Блока “Двенадцать" уподобление революционной России воскресающему Христу стало излюбленной темой той “мессианистической" поэзии, которая пышно расцвела сейчас в Советской России...» [6, с. 131]. Однако, как в 1918 году отмечает С. Гордон, «фаталический оптимизм как бы заглушает чувство трагизма совершающегося. 0но лишь мигами мелькает, - и растворяется в пафосе веры» [6, с. 130]. Критик называет Есенина «народным поэтом» и подчеркивает: у всех «людей земли фатализм является наиболее естественным выражением их мироощущения, и трагедия - такое же явление в ряду прочих мировых явлений, как листопад, осень, смена времен года, рождение, расцвет и смерть...» [6, с. 131]. То есть удивительный сплав трагического и необходимого, фатально предназначенного судьбе Родины угадывается в этой поэме. Само же название «Пришествие» также неоднозначно. По мнению рецензента сборника «Мысль» М.0. Цетлина, это «пришествие большевистской революции» [6, с. 130]. А начальные три строчки неожиданно определяются как «пламенная молитва» [6, с. 130]. Однако, думается, если в этом произведении речь и идет о религиозности, то не о традиционной православной, а о созданной самим поэтом, о «есенинской вере». Эту мысль можно подтвердить словами В.Ф. Ходасевича: «...Силы и события даны им в образе воинов, бичующих Христа, отрекающегося Симона Петра, предающего Иуды и, нако- нец, Голгофы. Казалось бы, дело идет с несомненностью о Христе. В действительности это не так <...> Все образы христианского мифа здесь даны в измененных (или искаженных) видах, в том числе образ самого Христа...» [6, с. 131].

Как свидетельствуют дневники композитора, у Свиридова более «традиционные» религиозные убеждения [1, с. 60, 65, 95, 171-173]. Выбрав отрывок этой есенинской поэмы в качестве литературной основы второго номера своего сочинения, он, конечно же, видел в ней что-то близкое своему мировоззрению. Тем более отдельная часть циклического произведения, «вычлененная» из общего контекста, всегда приобретает несколько иной смысл. И в свиридовском прочтении это «Господи, я верую!» становится переживанием и болью человека старой, крестьянской Руси за свершившиеся события и за облик новой Родины. Поэтому для выражения трагических мыслей выбран суровый тембр баса. Его монолог сдержан, но могуч, как песнопения древнерусских богослужений. Интонация декламационная, но, пропеваемая как бы «через сопротивление» на предельном legato, она приобретает внутреннее напряжение. Показываются мощные чувства страдающего народа, предстающего в образе Божьего Сына, и потому мелодия, насыщенная широкими интервалами, охватывает большой диапазон. Ниспадающая по звукам тонического трезвучия и далее постоянно «вращающаяся» вокруг него, мелодия тонально четко определена: это строгий до минор.

Пример 3
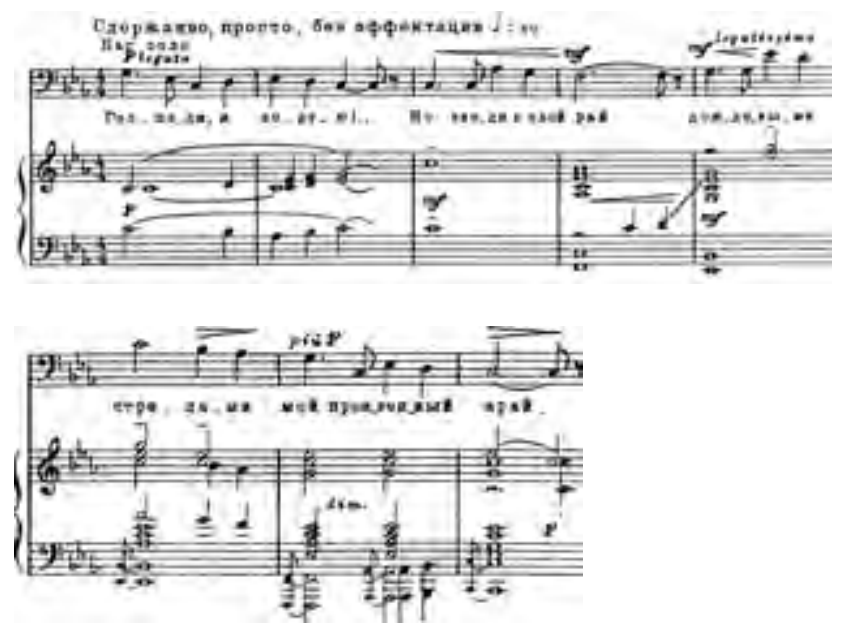

Структура номера, что для Свиридова редкость, квадратна: фразы занимают точно по восемь тактов, и таких фраз четыре. Музыкальный материал всякий раз повторяется, изменяется лишь сопровождение. Размер также квадратный четырехдольный. Темп неспешен, что сдерживает от возникающей аллюзии на колыбельную: слишком уж серьезны затронутые вопросы. Все это образует некое противопоставление нежной трехдольной первой части и служит признаком трагичности, драматизма, неизбежности происходящего.

Третья часть «3реет час преображенья...» написана на первые три четверостишия пятой главки «Преображе- 
ния» - другой поэмы Есенина, относящейся к 1917 году. Очевидно, что она, как и остальные поэмы революционных лет, отмечена неоднозначным отношением автора к происходящим событиям, выраженным в закодированной системе образов. «Пою и взываю: Господи, отелись!» [6, с. 25]. Уже в начальном четверостишии поэт запрятал некий смысл, проясняющийся только с комментариями самого автора. «0телись»- значит «воплотись» [7, с. 163]. Вероятно, хотел поэт сказать Богу, чтобы материализовался, явился в каком-нибудь реальном виде. И в этом отнюдь не богоборческая позиция поэта. Как объяснял Есенин П.В. Орешину, «...понимаешь ли, есть, сидит эдакий озорник! Ты знаешь, я к Богу хорошо относился, и вот <...>. Но ведь и все хорошие поэты тоже <...>. Например, Пушкин...» [8, с. 265-266, 268]. 06 этом же свидетельствует и В.Ф. Ходасевич: «Есенин обращался к своему языческому богу - с верой и благочестием. Он говорил: “Боже мой, воплоти свою правду в Руси грядущей"» [6, с. 133]. А воплощение правды, как и постройка грядущего мира, возможна только через преображение. То, что произошло когдато на горе Фавор близ Палестины с Иисусом, ожидает и Русь. Час приближается, оно уже «зреет», возвещая приход «светлого гостя». Эта метафора, заимствованная у Есенина, стала ключевой и дала название всему свиридовскому циклу. И, что символично, появляется она именно в третьем номере, подчеркивая в этом произведении сакральный смысл числа «три» ${ }^{1}$. Номер исполняется смешанным хором,

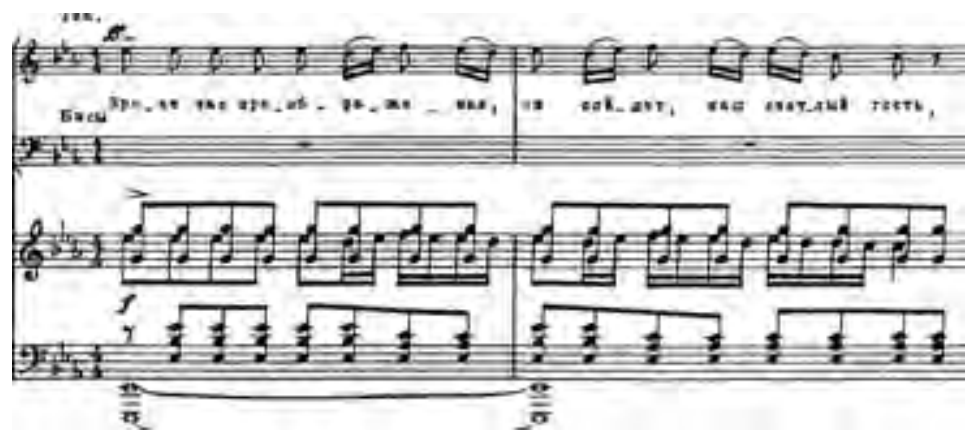
что представляет третью образную сферу - общенародную, соборную. Это выражаемые в массовом ликовании надежды и чаяния русских людей, слитых в едином порыве в предвестии чего-то праздничного и светлого. Темп быстрый, и мелодия тоже очень подвижная, упругая, вплоть до 17-го такта выписанная мелкими длительностями: восьмыми и шестнадцатыми. Она построена на секундовых интонациях как и в первой части; крутится в круговороте согласия знаменного распева. Возвращается и основной тональный центр, ми-бемоль мажор. Интересна метроритмическая структура: ритм остинатен и подвижен за счет синкопирования слабых долей такта шестнадцатыми и восьмыми. В сопровождении первая доля нечетных тактов акцентируется длящейся два такта октавой в низком регистре, на фоне которой ровные восьмые и шестнадцатые создают эффект перезвона разных по мощности колоколов.

С 17-го такта вступает весь хор, немного убыстряется темп и происходит укрупнение длительностей, как бы удвоение начальной ритмической формулы. Такие жесткие метроритмические конструкции несколько механистичны и ассоциируются с праздничными картинами народных массовых гуляний.

\footnotetext{
${ }^{1}$ На это указывает и то, что композитором использованы первые три четверостишия пятой главки есенинской поэмы; главные слова «он сойдет, наш светлый гость» троекратно повторяются.
}

Композиционная структура номера квадратна: общее количество тактов - 48. Первые 16 тактов занимают переклички теноровой и басовой партий. В стиле фугато четырехтактная фраза теноров сменяется остинантной вто́рой баса, расположенной на кварту вниз. С 17-го такта добавляются голоса, наращивается фактура и удлиняются фразы: две фразы по 8 тактов и заключительная, состоящая из 12 тактов. Новый вариант темы создает ощущение мощного прилива новых сил, праздничной ликующей толпы. На протяжении всей песни динамика сохраняется максимальной, $f$-ff, это номер-кульминация, первая яркая вершина цикла. Звенящие сочные колокола перекликаются с прозрачными колокольцами первой части, они возвещают об истинном всенародном торжестве. Первые три части экспонируют три образные сферы, три эмоциональных состояния и открывают путь к их дальнейшей модификации и варьированию в последующих номерах цикла.

Пример 4

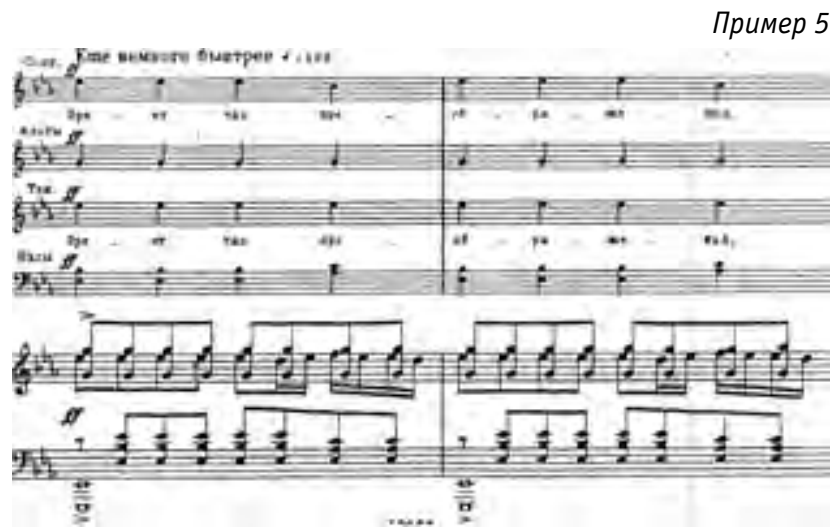

В основе четвертой части - «Гляну в поле, гляну в небо...»- лежит одноименное стихотворение Есенина, написанное, по одним источникам, в 1916 году, по другим - в праздник Успенья 1917 года. Последняя дата более вероятна, так как все стихотворение наполнено восхищением благодати и урожайности родной природы. Праздник Успения Божией Матери, отмечаемый 15 августа по юлианскому календарю², всегда был одним из наиболее почитаемых православной церковью. (По-видимому, праздник имел особое значение и для поэта: стихот-

\footnotetext{
228 августа по новому стилю.
} 
ворение помечено именно как «Успенье 1917 г.», а не «15 августа 1917 г.» [5, с. 173]). Время это знаменуется окончанием жатвы, уборкой урожая, началом осенних гуляний и хороводов. И Есенин передает это ощущение достатка, сытости, даруемого ширью и неохватными просторами. Возникает образ Родины-Рая, волшебный образ, заповедный и какой-то нетронутый: край «незапахан», и рощи «непасены», стада «неизбывны», вода «златоструйна», и даже руки «проливаются» молоком. Явленное воплощение крестьянской мечты. В том же архаичном ключе есенинские образы перетекают в свиридовскую музыку. Мелодика номера сплошь диатонична, натуральноладова. Она распевна, движется по широким интервалам, занимая большой диапазон, тональные центры постоянно смещаются; композитор словно нарочно обходит ладовые устои, создавая колеблющиеся красочные гармонии.

Пример 6
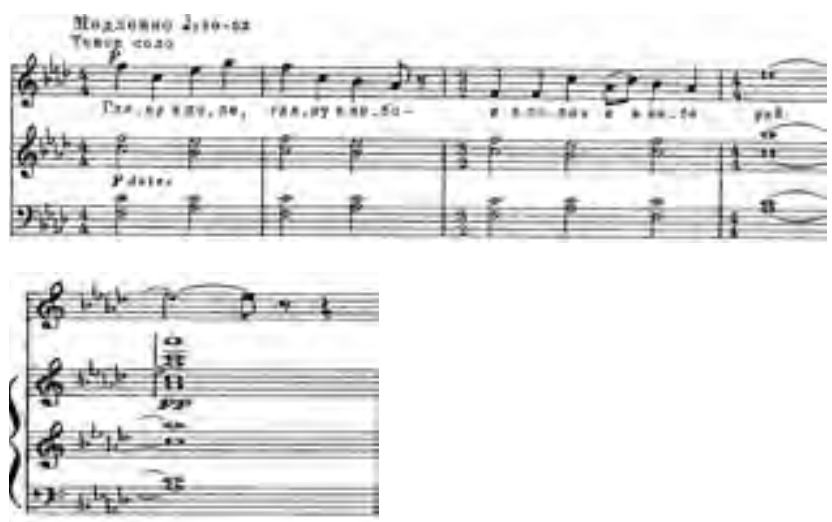

В основе гармонической системы лежит интереснейший полифонический принцип сочетания различных диатонических пластов: в тактах 11-14 выявляется сочетание трезвучий as-c-es и c-es-g, дающее медиантовые колебания гармоний ля-бемоль мажор - фа минор; в т. 15-17 - des-f-as и c-es-g.

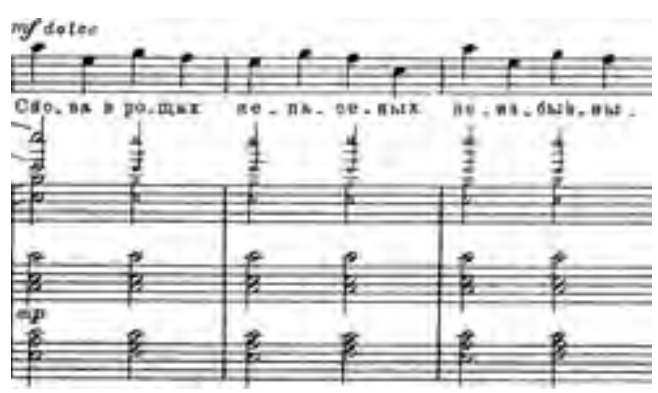

Пример 7

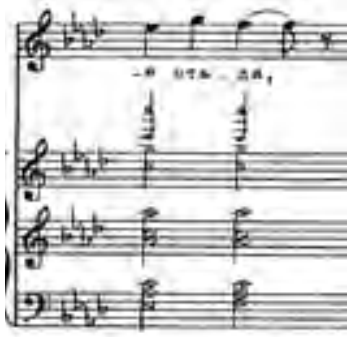

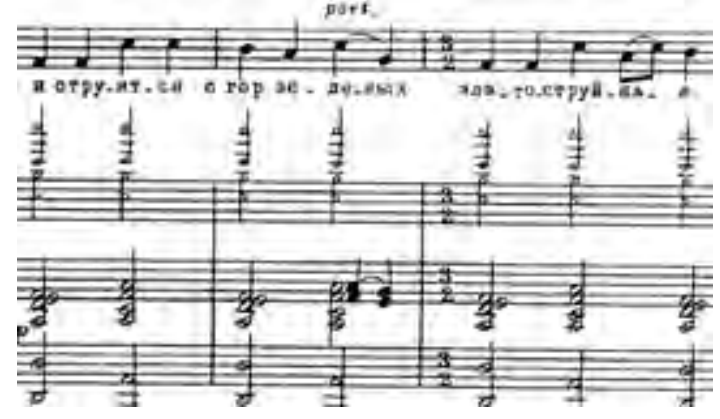

В 18-м такте образ «златоструйной воды» выражен необычным фонизмом квинтсекстаккорда малого минорного септаккорда от соль, наложенного на басовую октавную педаль на ноте до, также продублированную верхними голосами.

Пример 8
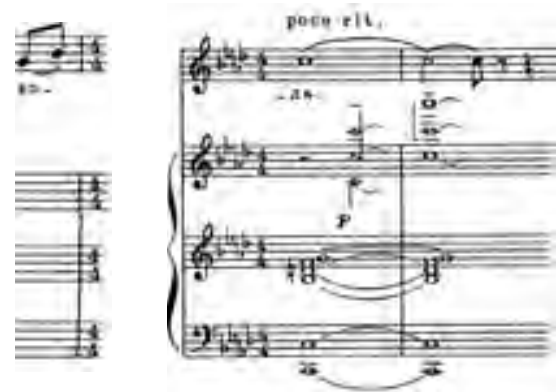

Такая полигармоническая организация аккордов идет от использования композитором трезвучных и терцовых структур не как подчиненных элементов, определяющих тональность, но как самостоятельных фонических созвучий. С этим принципом органично сочетается и излюбленная русской музыкой плагальность. Кварто-квинтовые звучности слышны уже в начальном такте. Рассказать об этом райском месте поручено тенору, причем очень высокому: партия выписана в верхней тесситуре, в ней встречаются ля-бемоль, си первой и даже до второй октавы. Умиротворенный темп отзывает к неспешному движению колыбельной первой части. Снова все подчинено слову, логическому разворачиванию смысловых фраз, без какой-либо механистичности. Поэтому непостоянен размер: четырехдольность сменяется трехдольностью, часты длинные залигованные ноты. Мерные колокольные удары слышны на протяжении всего номера, но особо ярко они проявляются в кульминации «0, я верю...». Это наиглавнейшие слова во всем цикле, отмеченные высочайшим до третьей октавы tenuto у солиста, $f$ и гармонически неожиданным сочетанием трезвучия as-c-es с секстаккордом des-f-b.

Эта часть образует композиционную и драматургическую «арку» со второй частью, она продолжает монологическую линию цикла в более оптимистичном, просветленном ключе.

Для пятой части цикла композитор выбрал финал есенинской поэмы «Инония». Поэт, собственно, сам от- 
деляет его от всего предшествующего содержания, называя песней и ставя кавычки: «Капает песня с гор». То есть создается «жанр в жанре», песня в поэме. «Инония», законченная в январе 1918 года и напечатанная в майском номере «Знамени труда», получила при жизни поэта, пожалуй, самый широкий резонанс в среде критиков и литераторов. В их рецензиях сразу же обозначились противоположные мнения.

Пример 9

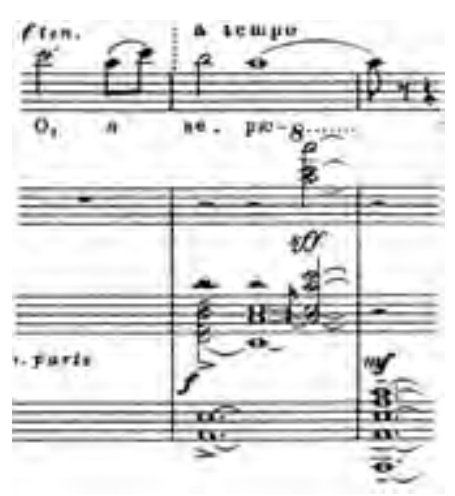

В положительных отзывах выражено понимание, сочувствие и даже восхищение созданным произведением.

Так, И.А. Оксенов в статье «Слово пророка» пишет, что «не всякому дано сейчас за кровью и пылью наших (все же величайших) дней разглядеть истинный смысл всего совершающегося <...> К последним немногим, отмеченным Божией милостью счастливцам, принадлежит молодой рязанский певец, Сергей Есенин, выросший за три года в большого народного поэта <...> Венцом его поэтической деятельности кажется нам поэма "Инония" <...> Пророчески звучит эта поэма. Небывалой уверенностью проникнуты её строки. Головокружительно высоки её подъемы» [6, с. 141].

Сравнение поэта с пророком продолжает и Иванов-Разумник в статье «Россия и Инония»: «“Тело, Христово тело, выплевываю изо рта", - говорит. И, быть может, многие увидят в последнем только голое "кощунство", в то время как в нем - лишь разрыв с историческими формами христианства <...> Вся “Инония" - не богохульство, а богоборчество; всякое же богоборчество есть и богоутверждение нового Слова <...> Поэмы Блока, Есенина, Белого - поэмы “пророческие”, поскольку каждый подлинный “поэт" есть “пророк”. И все истинные поэты всех времен - всегда были “пророками" вселенской идеи своего времени, всегда через настоящее провидели в будущем Инонию» [6, с. 142].

После повторной публикации в составе сборника «Россия и Инония» издательством «Скифы» в Берлине поэма вновь всколыхнула печать русского зарубежья. На этот раз эмигрантские оценки носили явно выраженный политический характер. Например, М.О. Цетлин пишет следующее: «Поэма “Инония" очень талантлива, очень ритмична и образна. Напрасно осмеяно в газетах столько нашумевшее мистическое “божье теление". Те, кто знали по прежним стихам Есенина про его страстную истинно крестьянскую любовь к коровам, - не удивятся, что именно этот образ явился у поэта для символа таинственного рождения в мире нового, в данном случае - страны Инонии. Поэт, видно, искренне вспыхнул радостным ожиданием нового мира. Увы, теперь мы знаем, во что преобразилась эта крестьянская “Инония" и что стало с её хатами и нивами. Но ведь тогда этого ещё не было видно» [6, с. 145].

Важную мысль проводит А. Киселев в статье «Мессианство в новой русской поэзии: “Пророк Есенин Сергей"»: «<...> 0бращаясь к старому миру, олицетворенному в виде Америки, технически мощной, но слабой своей бездушностью и безверием, поэт ещё раз ставит русскую тему о примате религиозно-этических ценностей над ценностями материальной культуры. Эта культура несет в себе зародыши гибели, опустошения души, упирающейся в бессмысленное накопление, ибо "проволочные лучи", которыми культура окутала землю, "не осветят пришествия" нового Бога <...>. Но что мы стоим на великом переломе, что в душе нового человека назревают новые ценности, без которых “нечем жить”, - в этой основной мысли “Инонии" её значение, переходящее за грани текущего дня» [6, с. 145].

В отрицательных отзывах критиков преобладает ирония, доходящая до сарказма, обвинения в «нездоровых крестьянских настроениях» и богоборчестве. Последнее вызывало особенное недоумение у литераторов. Дескать, как смог поэт от сохи, столько лет использовавший образы Христа, Богоматери, Миколы, вдруг взять и отказаться от Бога. «Нет, сколько бы ни извинялся Есенин <...> за "самый щекотливый этап" свой - религиозность, сколько бы ни просил читателя "относиться ко всем его Иисусам, Божьим Матерям и Миколам" как к “сказочному в поэзии", для нас ясно: весь религиозный строй души его к куцему позитивизму сведен быть не может. По прежнему взыскует он нездешних “неведомых пределов". Неизменна его религиозная устремленность, порыв к Божеству <...>» [6, с. 147]. И.Н. Розанов отмечает, что «поэты из народа пошли гораздо дальше А. Блока и А. Белого: Христос не только с нами, наш, но мы, т. е. революционный народ, и Христос - это, в сущности, только две ипостаси божества; а если “мы сами Христы", то никакого другого и не нужно - вот итог, к которому приходит Есенин в своей последней поэме “Инония" <...>» [6, с. 143].

Свиридов очень умно и тонко обходит все эти спорные острые моменты поэмы. Как и в предыдущих частях, он выбирает поэтический отрывок, наделяет его новыми идеями и мягко вводит в музыкальную жизнь цикла, образуя «арку» с третьей частью, становясь ее мощной вариацией. Поэтому мелодия снова строится на интонациях знаменного согласия и является преобразованием темы третьей части. Она распевна, хотя и ограничена лишь диапазоном секунды. Первая доля как у хора, так и в сопровождении выделена акцентом, подобно мощному колокольному удару. 
Особая роль поручена унисону, проявляющемуся во всей фактуре части. Унисон альтов-басов и сопрано-теноров дублируется и в сопутствующих инструментальных партиях. Дающий эффект усиления, он приобретает сакральный смысл, уходя своими корнями к раннехристианской философской мысли первого тысячелетия [9]. Динамика части, как и в третьем номере, максимальна. Ритмическая структура составлена из жестких ритмоформул, являющихся как бы удвоенным вариантом начальной темы третьей части. Неизменность, монотонность движения снова создает ощущение механистичности, некоей неконтролируемости процесса. Интересно ритмическое решение кульминации «Спас»: здесь взаимодействуют четыре различных музыкальных пласта. Очень характерный для Свиридова принцип комплементарности реализуется в сочетании нижнего, помеченного акцентом, октавного слоя залигованных целых длительностей с точкой с располагающимися над ними трезвучными ударами четвертей, еще выше - перезвонами восьмых и, наконец, самым верхним слоем - трезвучным хоровым аккордом, метроритмическим двойником баса.

Пример 10

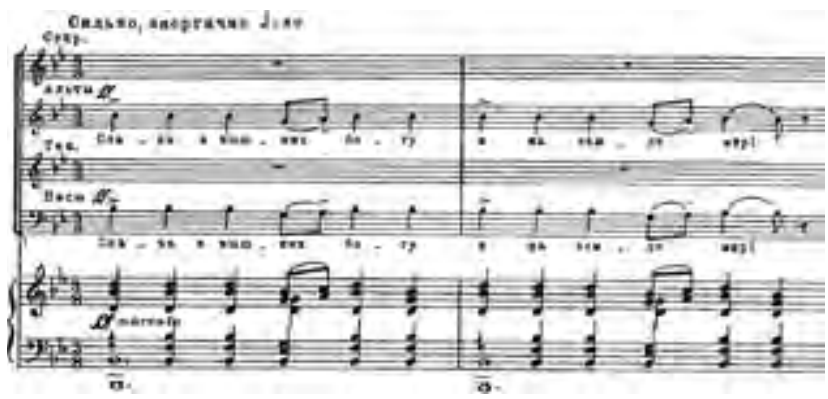

Пример 11
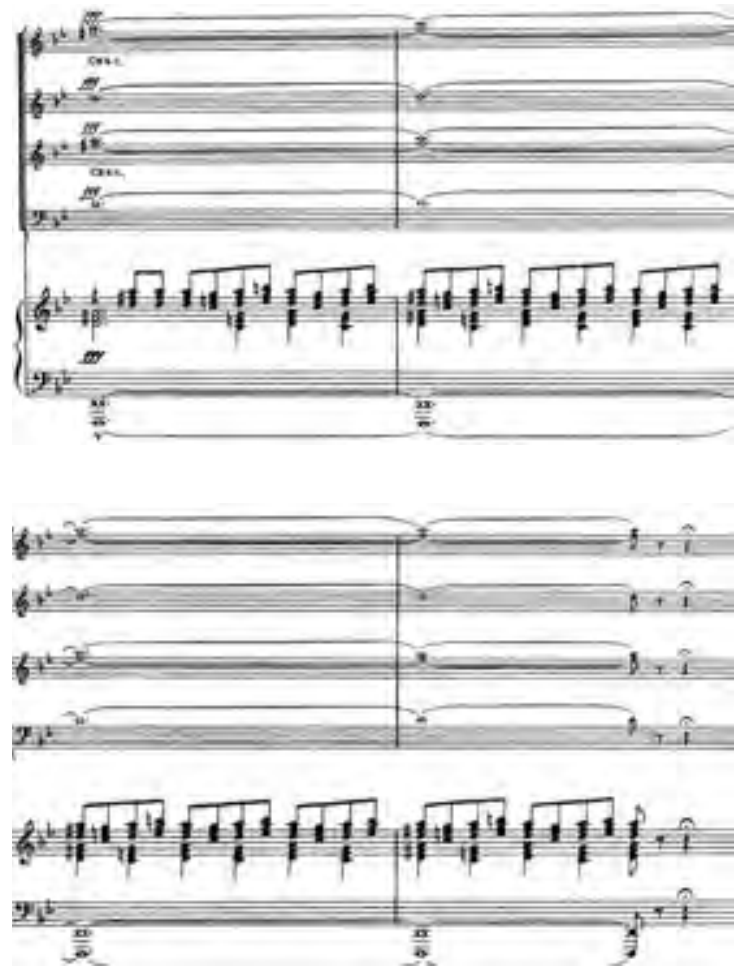

Пример 12
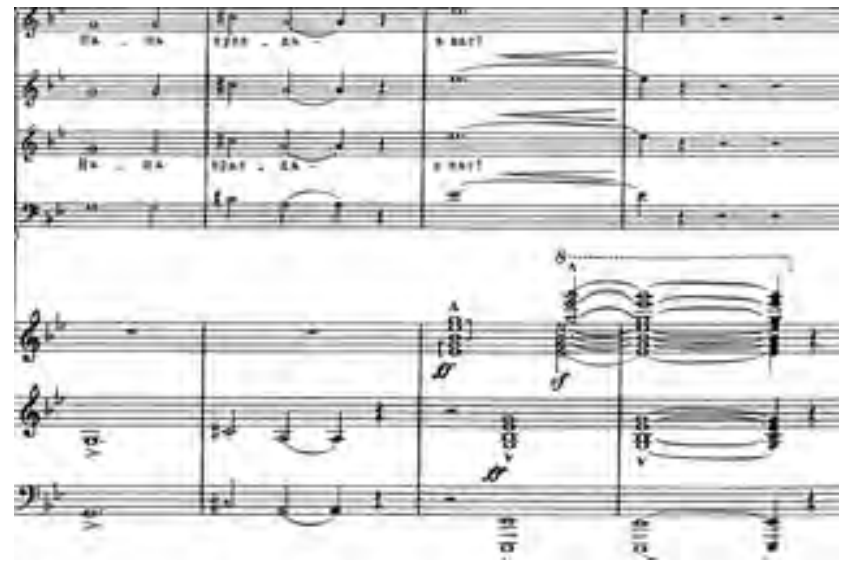

Эти пласты, порученные различным инструментальным группам, выделяются еще и тембрально. Взаимодополняя друг друга, они образуют яркую колокольную кульминацию, неожиданно сменяющуюся эпизодом «Наша вера - в силе. Наша правда в нас!». Происходит как бы «сбой» налаженного пульсирующего метроритмического движения на тяжелые целые и половинные длительности. Мелодия, основанная на восходящих кварто-квинтовых интонациях, среди которых впервые в цикле появляется тритон, оказывается без определенного тонального центра. Показательно, что здесь снова композитор использует унисон всех хоровых и инструментальных голосов.

Думается, что именно эти заключительные такты выражают авторскую позицию к Революции, Гражданской войне как к чему-то насильственному и неестественному. И весь номер, бодрый и, казалось бы, ликующий в начале, вдруг приобретает оттенок тяжелой, неконтролируемой, не способной к развитию машинной силы, все подчиняющей своему движению и замкнутой на самой себе. Сообразно принципу концентрической формы, эта часть, развивая и варьируя третью, знаменует также начало обратного движения, словно движения «вспять», возвращения к началу.

Финал собирает все мелодические, гармонические линии, синтезирует три образные сферы цикла: МатьРоссия, прошедшая через великие испытания, кровью искупившая грехи, с новой мудростью и опытом глядит с надеждой в будущее и видит там свет и благодатную жизнь в новом мире, воссоединенном с Богом и Вселенной. Звучание ее колоколов соборно, но тихо и прозрачно, светлопечально. Образуя «арку» с первой частью, финал замыкает круговую драматургию цикла.

В просветленном соль миноре выплывает тягучее соло сопрано «Покраснела рябина...». Это тембральная перекличка с начальной колыбельной; только на этот раз она знаменует воссоединение: звучит не отдельный голос, а целая хоровая партия. Слышна та же неторопливая трехдольность и мерные колокола оркестра. Вновь проглядывает образ Спаса, и во всей природе ощущается божественное присутствие. Есенинское стихотворение датировано 1916-м годом, дореволюционным временем, 
когда поэт еще не был охвачен богоборческими идеями. В нем - совсем другой Есенин, еще не написавший революционных поэм, не познавший страну Инонию. И то, что композитор выбирает именно это стихотворение для финала, знаменательно. Ведь финал - итог всего произведения, место, куда стремилось все развитие. Получается, что всё действие возвращается в тихую, крестьянскую, дореволюционную Россию с Богоматерью и Спасом, столь близкую и знакомую как композитору, так и поэту. Отсюда и круговая концентрическая форма, и ритмические рефрены, и бесчисленные тематические круговые варьирования. Мелодия «словно Вольга», герой русских былин, князьдружинник или волхв-чародей, широка, по-архаичному неспешна и диатонична. Она, вплоть до кульминации «Дня закатного жертва...», повторяет один и тот же рисунок с характерными пролонгациями в конце, изменяется лишь состав исполнителей: вначале партия сопрано, затем альты, потом тенора с басами и, наконец, весь хор.

Пример 13
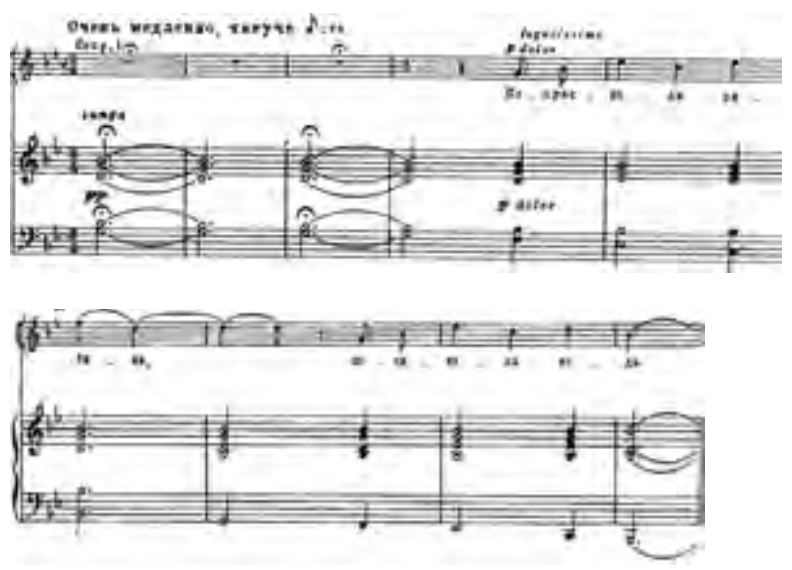

Но, несмотря на это, впечатления однообразности и монотонности не происходит: обновляется тембральное звучание хора, да и оркестровые аккорды также освежаются постоянно сменяющимися звучностями. Общехоровая кульминация в шестидесятом такте знаменуется мощнейшим fff, сменой мелодического рисунка и прорывом в высокую тесситуру. Сама фраза «Дня закатного жертва...» является парафразом библейской Книги пророка Амоса ${ }^{3}$. Вот такой мощный образ искупления грехов становится кульминационным для всего цикла. Он выделяется особыми гармоническими созвучиями и плавно перетекает в оркестровое окончание с неожиданными хроматическими модуляциями. Тональная сфера цикла преимущественно бемольна; диезные же и вообще хроматические звучности как бы приберегаются композитором для особенно важных мест, одним из которых становится именно конец финала. Это сдержанное, лирическое приветствие зарождающейся после «искупительной жертвы» новой жизни новой страны. Это великая заря, занимающаяся на волнах исторического развития государства.

Так в этом произведении уникальными средствами выразительности композитор рисует простой и скорбный, но в то же время преображенно-возвышенный, прошедший через стихийные, во многом неизбежные события начала XX века, образ России. Индивидуальный творческий почерк Свиридова удивительно органично сочетается С исконно русской, глубинной поэзией Есенина, являя собой еще один уникальный образец русской музыкальной культуры. Это глубоко символичное творение мастера. В нем Свиридов одновременно словно и оглядывается в прошлое и всматривается в будущее, находя в нем новые пути добра и света, по которым устремится в своем развитии Преображенная Русь.

\section{Список литературы}

1. Свиридов Г.В. Музыка как судьба. - М.: Молодая гвардия, 2002.

2. Георгий Свиридов. Светлый гость. Кантата для солистов, смешанного хора и симфонического оркестра. Переложение для пения с фортепиано автора. - М.: Музыка, 1979.

3. Дмитриев О.В., Степенко Г.В. Словарь итальянско-русский и русско-итальянский. - Киев: Перун, 2002.

4. Баратынский Е. Полное собрание стихотворений в двух томах / под ред. Е. Купреянова и И.Н. Медведева. - Т.1. М.;Л.: Советский писатель, 1936.

5. Есенин С.А. Полное собрание сочинений в семи томах. Т. 1. - М.: Наука-Голос, 1995.

6. Есенин С.А. в воспоминаниях современников. В 2 т. Т. 1. M., 1986.

7. Есенин С.А. Полное собрание сочинений в семи томах. Т. 2. - М.: Наука-Голос, 1995.

8. Есенин: Жизнь. Личность. Творчество. - М., 1926.

9. The harmony of the spheres. A sourcebook of the Pythagorean tradition in music // ed. by Joscelyn Godwin. - Rochester (Vermont), 1993.

10. Игумен Арсений (Соколов). Книга пророка Амоса. - Новоспасский ставропигиальный мужской монастырь, 2012.

\footnotetext{
${ }^{3}$ См. [10]. Согласно легенде, в Самарии и других израильских городах царили порок и разврат. В один день по велению Божию пришел туда пастух Амос и, пораженный нечестивостью, начал проповедовать. Он поведал, что явившийся ему Господь открыл страшную весть: все грешники погибнут от меча, и сам Израиль как «грешное царство» будет стерт с лица земли. «И будет в тот день, говорит Господь Бог: произведу закат солнца в полдень и омрачу землю среди светлого дня». Так и случилось, Израильское царство погибло, исчезли десять колен Иакова. Но, по слову Господню, эта гибель явилась искупительной жертвой и предвестием будущего возрождения Израиля. Что также исполнилось, хотя об этом не мог знать Есенин, но в своих «Ключах Марии» он ссылается на Книгу пророка Амоса.
} 